Program: Materials and Structures

DOE Task: 26 - LMFBR Flexible Pipe Joint Development

Program Manager: R. E. Schnurste in Reporting Period: May 1978

General Order: 09278
Project Manager: R. V. Anderson Category:

Subaccount: A11

189a Number: SA015

Principal Investigators: C. Dunn, K. Jaquay, P. Horton, P. Ferry

$$
\text { QTO3 T6SF>6026 }
$$

I. PROJECT OBJECTIVES

\title{
DOE/SF/76026- TS4
}

The primary objective of the Flexible Pipe Joint Development Program is the qualification of a PLBR-size primary loop flexible piping joint to the ASME B\&PVC rules which are currently under development in conjunction with this program. Achievement of this primary objective requires significant efforts in several areas. These areas include: (1) the support of ASME Code rules for the design and construction of flexible piping joints; (2) the design of a PLBR-size gimballed flexible piping joints; (3) the development of a lubricant system for the hinge assembly of the flexible piping joint; (4) the development of manufacturing techniques for fabrication of PLBR-size bellows and flexible joint hardware; (5) the developmental and verification testing of subscale bellows in support of the ASME rules; and (6) the qualification testing of a PLBR-size gimballed flexible piping joint in an elevated-temperature sodium environment. Completion of efforts will culminate in the acceptance of a PLBR-size flexible joint design to the approved ASME Code rules governing these components.

\section{PROGRESS DURING REPORTING PERIOD}

\section{A. Class 1 FLEXIBLE JOINT CODE APPROVAL SUPPORT}

A methodology for accelerating elevated temperature life tests of bellows was established which relies on demonstrating equivalence of predicted damage between the actual service histogram and a basic test histogram. These predicted damages are computed using the failure definitions in Code Case 1592 and a consistent analytical method. Depending on how the predicted damage compares to the acceptable damage per Code Case 1592, a demonstration factor is established for the basic test histogram which dictates how many times the test histogram must be imposed on the expansion joint without failure for the design to be acceptable. This demonstration factor reduces to the Appendix II test factors for low temperature service when the failure mode is either strictly creep or fatigue. 


\section{DISCLAIMER}

This report was prepared as an account of work sponsored by an agency of the United States Government. Neither the United States Government nor any agency Thereof, nor any of their employees, makes any warranty, express or implied, or assumes any legal liability or responsibility for the accuracy, completeness, or usefulness of any information, apparatus, product, or process disclosed, or represents that its use would not infringe privately owned rights. Reference herein to any specific commercial product, process, or service by trade name, trademark, manufacturer, or otherwise does not necessarily constitute or imply its endorsement, recommendation, or favoring by the United States Government or any agency thereof. The views and opinions of authors expressed herein do not necessarily state or reflect those of the United States Government or any agency thereof. 


\section{DISCLAIMER}

Portions of this document may be illegible in electronic image products. Images are produced from the best available original document. 
An interim two day meeting of the TF Class 1 Bellows was held at AI to discuss this proposed revision to the life testing rules and other items pertaining to the Code Case design rules. The proposed revision was well received by the Task Force and will be included in the next draft of the rules. Bob Swindeman of ORNL who had previously commented on accelerated testing difficulties could not identify any specific shortcomings of the proposed approach, however, he would need more time to examine the implications of the approach. Bob Campbell of EDAC presented a summary of his efforts for AI on accelerated tesing and was quite active in discussion on the subject.

Dr. Porowski of $0^{\prime}$ Donnell and Associates discussed a proposed revision to the creep bounding technique he has previously completed for AI. The revision extended the applicability to loadings with cyclic primary stresses, however, it was fairly conservative and further work would be needed to make the technique a more practical design tool.

Other discussions centered on the secondary pressure boundary criteria and written comments received from reviewers of the Code Case. Due to a comment suggesting more definitive guidelines be provided for acceleration of the pressure demonstration tests (as was done for the Life Tests) and a need by some attendees to further digest new revisions, it was agreed to not submit the Code Case for WG-PD approval at June Code week. Nevertheless, the progress made at this interim meeting was very encouraging and it should result in a considerabiy better Code Case for submittal to the higher committees.

Action Items were accepted to revise the Code Case per the meeting discussions and prepare a position paper supporting particular details of the proposed accelerated testing methodology.

Meeting minutes were prepared and sent to the chairperson for approval prior to mailing out to the attendees.

\section{B. ENGINEERING AND DESIGN}

The subscale bellows drawing and assembly drawing (including the flanges) were revised for the shorter end-tangent.

The CRBRP Thermal Transient event descriptions contained in the flexjoint design requirements, document N112TI240003, were combined and enveloped to provide 
a worst case design histogram for bellows screening analyses. The screening program used for bellows resiponse predictions was extensively modified to account for: (1) fabrication tolerances, (2) differences in predicted values observed when comparing these to finite element results, (3) end tangent effects on end convolution behavior indicated by finite element results, (4) angulation and creep effects on stability indicated by previously developed stability prediction techniques, (5) parameter computations needed to utilize previously developed bounding techniques on creep ratcheting, and (6) stress intensity calculations considering sign and Poisson effects observed in finite element solutions.

Bellows design runs utilizing the above updated screening program were initiated and results compared to developed acceptance criteria per the proposed Code rules. Early indications are that inelastic solutions will be necessary to show adequacy with respect to the proposed strain limits. Also, the flow sleeves in the expansion joint will need to be considered as a restraint effect preventing bellows squirm under the postulated 100 psi pressure pulse Faulted event. All other design criteria appear to be easily satisfied utilizing elastic analyses. Upon selection of the tentative geometry, detailed finite element analyses will be employed to demonstrate design adequacy. An internal memo covering "Screening Rules for Full-Size Bellows" was completed, and this will be the basis for a topical report.

The expansion joint hardware was redesigned to afford better thermal stress resistance and stress screening calculation are underway to establish reasonable geometry for the followup thermal and stress finite element analyses. Three different layout concepts are being investigated at this time.

Data reduction of the subscale bellows pretest series $(P)$ has been initiated. A11 data has been retrived and efforts are continuing to reduce it to a format indicative of information needed to establishing a meaningful Test Series 1.

\section{MATERIAL DEVELOPMENT \\ 1. Friction and Wear Tests}

An internal memo covering "Selection of Bearing Materials for Commercial LMFBR Flexible Joint Applications" was completed, and this will be the basis for a topical report. 


\section{Fatigue Tests}

Fatigue tests data of annealed Type 316 stainless steel were analyzed. The fatigue life of notched specimens was plotted as a percentage of smooth specimen life against the reduction of specimen thickness in the presence of notches (nominal notch depth $=2,4$, and 8 mils in 36-mil thick specimens). Figure 1 shows that there was a considerable reduction in fatigue life between $70^{\circ}$ and $1000^{\circ} \mathrm{F}$ when the thickness was reduced only about $5 \%$.

Similar fatigue tests were also conducted on annealed Type 321 stainless stee1. Figure 2 shows that Type 321 is not as notch-sensitive as Type 316 . Note also that Type 321 is more notch-sensitive at $1000^{\circ} \mathrm{F}$ than at $70^{\circ} \mathrm{F}$.

Some additional tests will be carried out to substantiate the trends indicated in both Figures 1 and 2 . Additional tests at other strain rates have been proposed.

\section{COMPONENT VERIFICATION TESTING AND DEVELOPMENT SUPPORT}

Testing on the Series $P$ bellows was completed with a demonstration for the ASME Task Force on Class 1 Bellows. Large amplitude ( $\pm 1-1 / 2$ in.) axial strain cycling and pressurization to end tangent deformation failure ( $\approx 175$ psig) were demonstrated. Movie footage was taken of this testing.

To reduce the overall test program time, Test Series 3 has been rescheduled ahead of Test Series 2. This will prevent a need for the MTS setup used in both Test Series 1 and 3 to be dismantled in order to setup for Test Series 2 .

\section{E. MANUFACTURING DEVELOPMENT \\ 1. Subscale Bellows Procurement}

The final unit of the initial subscale procurement from Metal Bellows was received. The units from Zallea Brothers are now scheduled for June receipt.

Bids for the procurement of 30 additional 12 convolution bellows and seven 30-convolution bellows (for stability testing) were received. These bellows will provide the units required to complete the subscale test program. The order will be placed in June with delivery this fiscal year. 


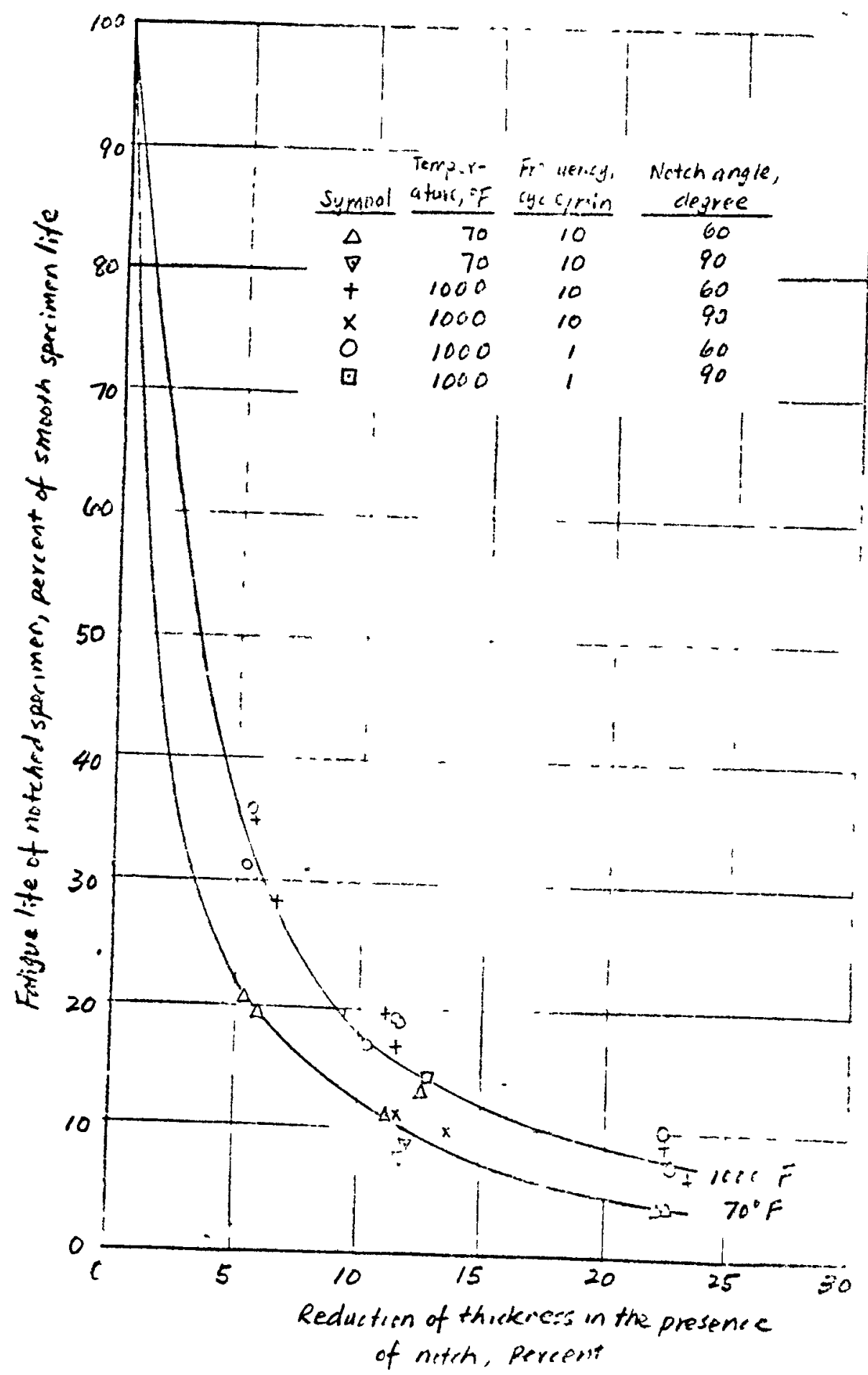

Figure 1. Effect of Notch On Fatigue Life At 1.08\% Strain Amplitude of Annealed Type 316 Stainless Steel 


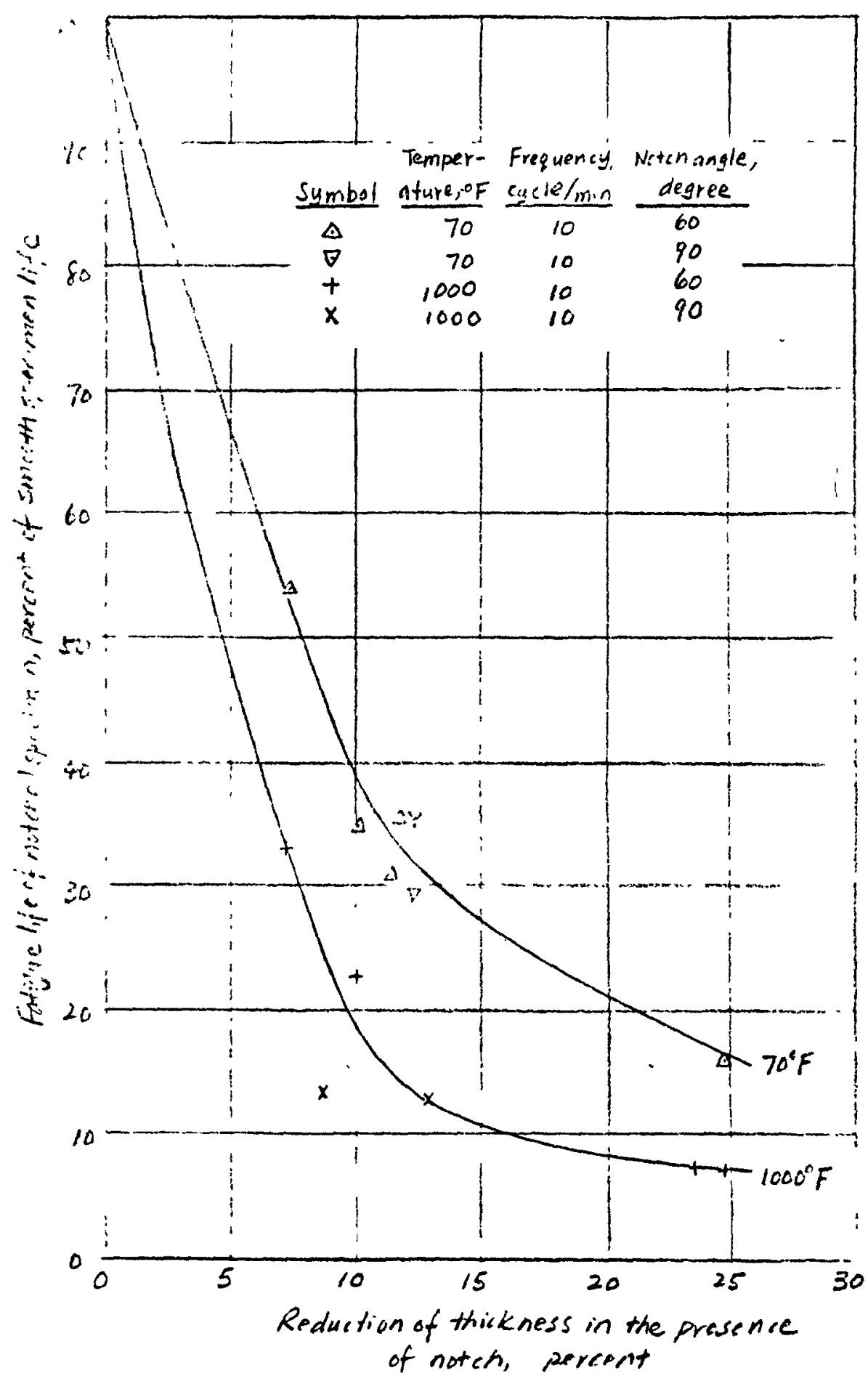

Figure 2. Effect of Notch On Fatigue Life At $1.08 \%$ Strain Amplitude of Annealed Type 316 Stainless Steel 
The end tangent test bellows was received from Metal Bellows. Design for modification of the weld fixture for the shorter end tangents was completed. Modification of the tooling, welding of the flanges, and hydrostatic test to demonstrate the shorter end tangent should be completed next report period.

Quotes were received from Metal Bellows and Ametek-Straza for shortening the end tangents on their three test bellows. The bellows will be shipped to them with a hold pending outcome of the hydrostatic test.

\section{Subscale Bellows Examination}

Bellows S/N 008, the last production unit to be delivered, was visually examined for surface defects. Very minor defects were observed; however, dimples caused by their expanding die forming process are still detectable although less pronounced.

A portion of a test bellows has been potted and cut out for destructive examination including grain size determination, photo-micrographs and convolution profile measurements.

\section{Weld Radiography Study}

Welds on 0.036 and 0.062 stainless steel sheet stock failed to produce porosity (other than a pore or two) even though weld engineering performed the welds under the most adverse conditions. Attempts to dril1 0.005, 0.007, and 0.010 pores in the welds did not materialize because the drills broke due to bushing clearance in the high speed motor utilized.

\section{IMPACT ON LMFBR PROGRAMS}

This project specifically addresses the use of bellows expansion joints in the primary loop of a large-scale LMFBR. Design and fabrication development, coupled with ASME approval of flexible joints, would allow minimization of primary piping runs and component-to-component spacing. The reduction in primary piping size is directly equatable to containment building size reductions and much reduced overall plant costs. 


\section{SCHEDULE}

The various activities and milestones for the Flexible Joint Development Program are shown in Figure 3. The schedule has been revised to reflect the impact of the shortened end-tangents required for the subscale bellows. 
FLEXIBLE JOINT DEVELOPMENT PROGRAM

GFY 1978 SCHEDULE (REVISED 6-12-78)

\begin{tabular}{|c|c|c|c|c|c|c|c|c|c|c|c|c|c|}
\hline \multirow{2}{*}{\multicolumn{2}{|c|}{ ACTIVITY }} & \multicolumn{12}{|c|}{ GFY 1978} \\
\hline & & OCT & NOV & DEC & JAN & FEB & MAR & APR & MAY & JUN & JUL & AUG & SEP \\
\hline \multicolumn{2}{|c|}{$\begin{array}{l}\text { SUBTASK A - CLASS } 1 \text { FLEXIBLE JOINT } \\
\text { CODE APPROVAL SUPPORT }\end{array}$} & & & & & & & & & & & & \\
\hline A1. & $\begin{array}{l}\text { NOVEMBER CODE COMMITTEE } \\
\text { MEETING PACKAGE PREPARATION }\end{array}$ & & $\nabla_{A 1}^{A 1}$ & & & & . & & & & & & \\
\hline A2. & $\begin{array}{l}\text { JANUARY CODE COMMITTEE } \\
\text { MEETING PACKAGE PREPARATION }\end{array}$ & & & & $\nabla_{A 2}^{A 2}$ & & & & & & & & \\
\hline A3. & $\begin{array}{l}\text { MARCH CODE COMMITTEE } \\
\text { MEETING PACKAGE PREPARATION }\end{array}$ & & & & & & & & ' & & & & \\
\hline A4. & $\begin{array}{l}\text { MAY CODE COMMITTEE } \\
\text { MEETING PACKAGE PREPARATION }\end{array}$ & & & & & & & & & & & & \\
\hline A5. & $\begin{array}{l}\text { JUNE CODE COMMITTEE } \\
\text { MEETING PACKAGE PREPARATION }\end{array}$ & & & & & & & & & & & & \\
\hline A6. & $\begin{array}{l}\text { COMPLETE SIMPLIFIED DESIGN } \\
\text { TECHNIQUES TOPICAL REPORT }\end{array}$ & & & & & & & & & & & & A7 \\
\hline & $\begin{array}{l}\text { SEPTEMBER SUBMITTAL OF CODE } \\
\text { CASE TO HIGHER COMMITTEES }\end{array}$ & & & & & & & & & & & & $\nabla$ \\
\hline \multicolumn{2}{|c|}{$\begin{array}{l}\text { SUBTASK B - ENGINEERING AND DESIGN } \\
\text { OF LARGESCALE LMFBR PRIMARY LOOP } \\
\text { FLEXIBLE JOINTS }\end{array}$} & & & & & & & & & & & & \\
\hline & DEFINITION OF FULLSIZE REACTOR & & & & & & & & & & & & \\
\hline & $\begin{array}{l}\text { OUTLET LEG FLEXIBLE JOINT } \\
\text { REQUIREMENTS }\end{array}$ & & & & & $\Delta \mathrm{B2}$ & & & & & & & \\
\hline $\mathbf{B 3}$ & COMPLETE FINAL SUBSCALE & & & & & $\nabla \mathbf{B 3}$ & & & & & & & \\
\hline & SPECIFICATION & & & & & & & & & & & & \\
\hline B4. & $\begin{array}{l}\text { SUBSCALE BELLOWS END-TANGENT } \\
\text { DESIGN MODIFICATION }\end{array}$ & & & & & & & & $\triangle_{\text {B4 }}^{\text {B4 }}$ & & B5 & & \\
\hline B5. & $\begin{array}{l}\text { SUBSCALE TEST SERIES P DATA } \\
\text { REDUCTION }\end{array}$ & & & & & & & & & & & & \\
\hline B6. & $\begin{array}{l}\text { INITIATE PROCUREMENT } \\
\text { SPECIFICATIONS FOR FULLSIZE } \\
\text { BELLOWS AND JOINT HARDWARE }\end{array}$ & & • & & & & & & & & $\sum_{B 7}^{86}$ & & \\
\hline B7. & SCOPE LEAKAGE AND MOTION & & & & & & & & & & & & \\
\hline & DETECTION SYSTEM DESIGN & & & & & & & & & & & & \\
\hline B8. & $\begin{array}{l}\text { FINALIZE REACTOR OUTLET LEG } \\
\text { PIPING LAYOUT SELECTION }\end{array}$ & & & & & & . & & & & & & \\
\hline
\end{tabular}


FLEXIBLE JOINT DEVELOPMENT PROGRAM (CONTINUED)

GFY 1978 SCHEDULE (REVISED 6-12-78)

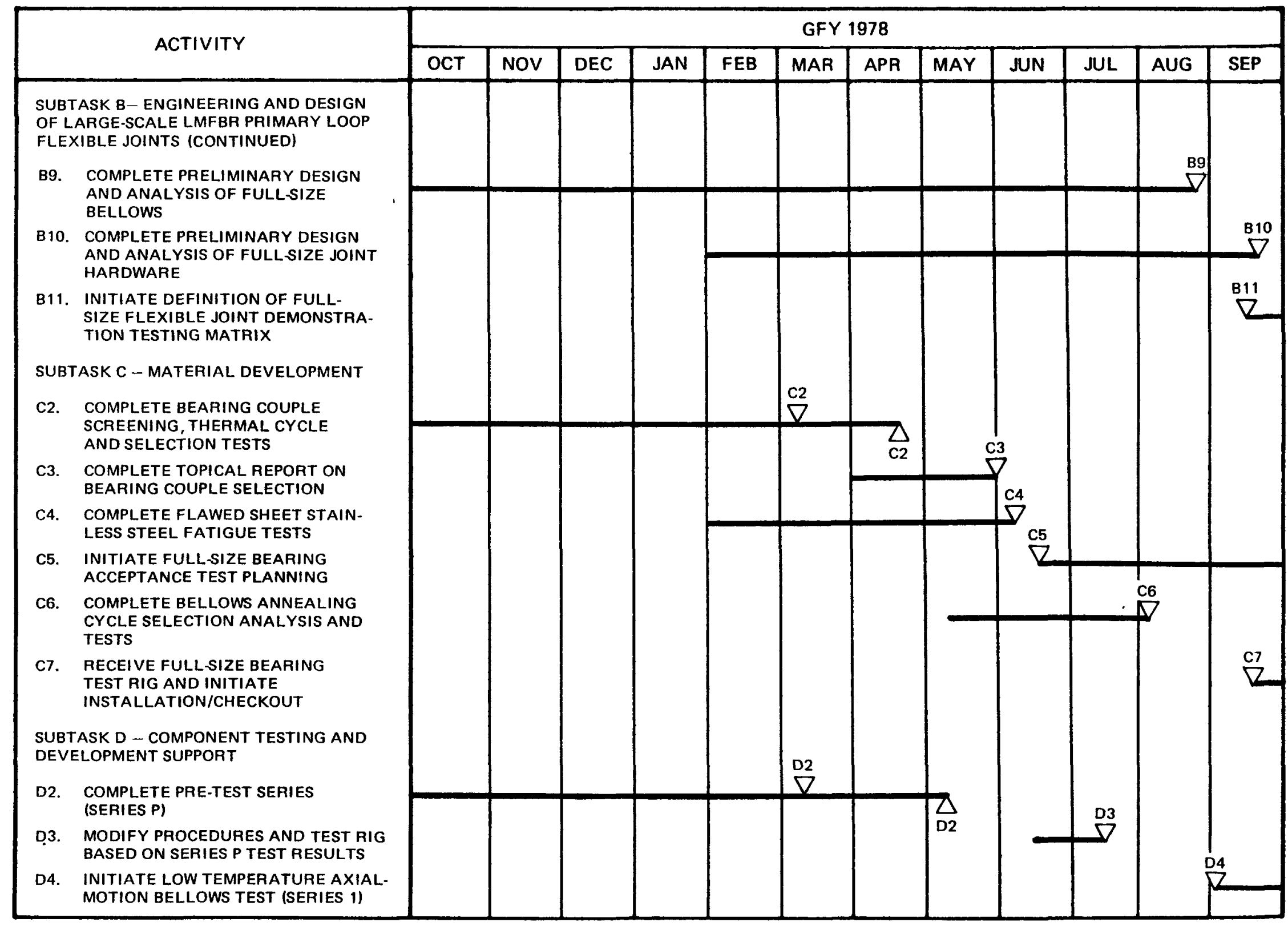


FLEXIBLE JOINT DEVELOPMENT PROGRAM (CONTINUED)

GFY 1978 SCHEDULE (REVISED .6-12-78)

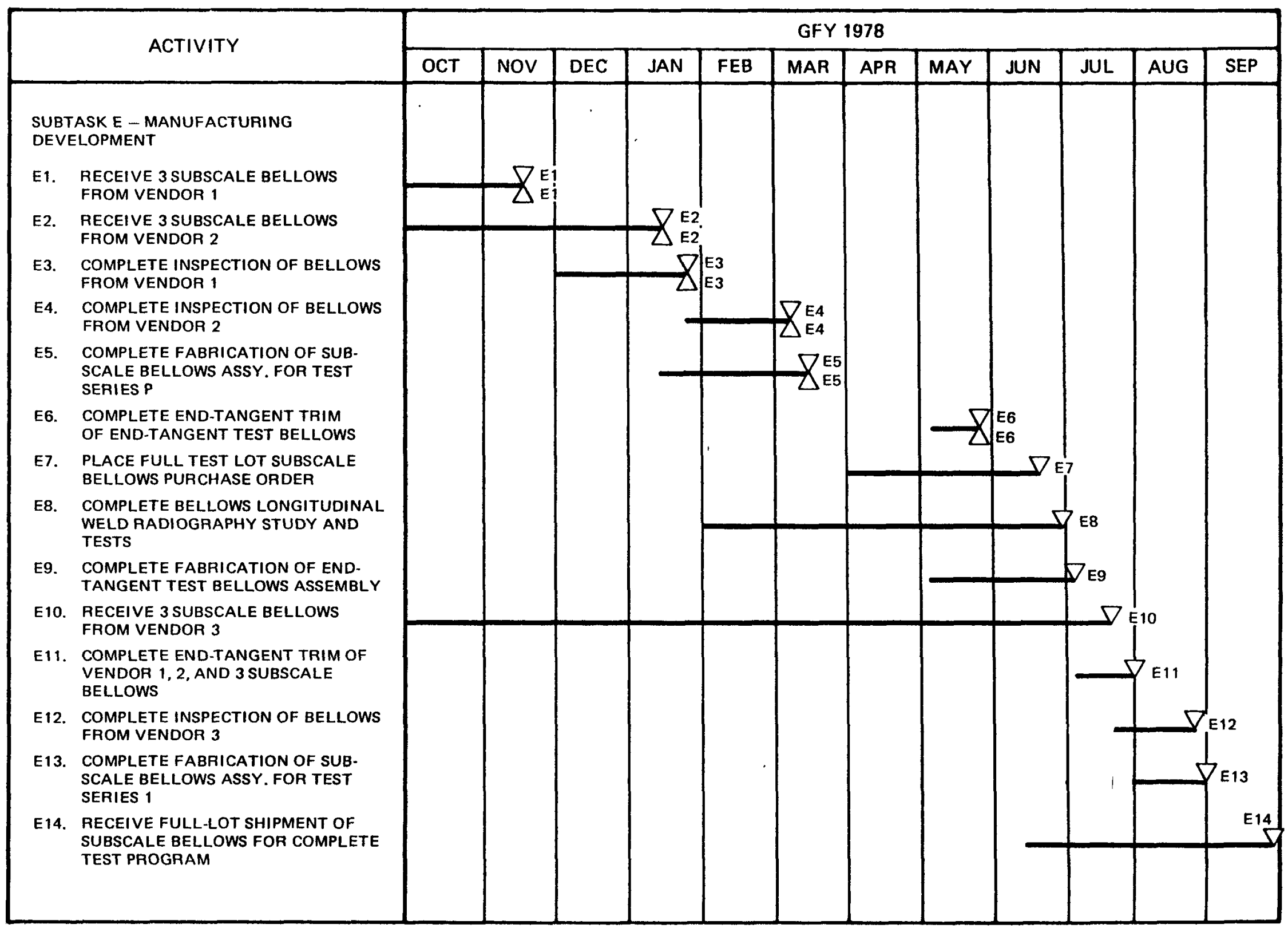

